

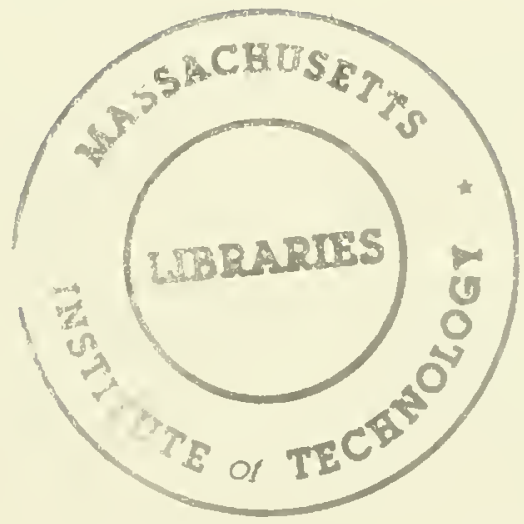




no. 3149 -

90

\section{WORKING PAPER \\ ALFRED P. SLOAN SCHOOL OF MANAGEMENT}

Paul M. Healy
MIT's Sloan School of Management

Krishna G. Palepu

Harvard Business School

and

Richard S. Ruback

Harvard Business School

Working Paper $\$ 3149-90$

\section{MASSACHUSETTS \\ INSTITUTE OF TECHNOLOGY \\ 50 MEMORIAL DRIVE \\ CAMBRIDGE, MASSACHUSETTS 02139}





\title{
DOES CORPORATE PERFORMANCE IMPROVE AFTER MERGERS?
}

\author{
by \\ Paul M. Healy \\ MIT's Sloan School of Management \\ Krishna G. Palepu \\ Harvard Business School \\ and \\ Richard S. Ruback \\ Harvard Business School \\ Working Paper $\# 3149-90$
}

April 1990

We thank Robin Cooper, George Foster, Michael Jensen, Bob Kaplan, Richard Leftwich, Mark Wolfson, Karen Wruck, and seminar participants at Baruch College, Carnegie Mellon, Columbia, Dartmouth, Duke, Federal Reserve Bank (Washington D.C.), Harvard, Michigan, MIT, NYU, Rochester, Stanford, USC, and U.S. Department of Justice for helpful comments on earlier drafts, Chris Fox and Ken Hao for research assistance, and the International Financial Services Center at MTT and the Division of Research at HBS for financial support. 


\title{
DOES CORPORATE PERFORMANCE IMPROVE AFTER MERGERS?
}

\begin{abstract}
We examine the post-acquisition operating performance of merged firms using a sample of the 50 largest mergers between U.S. public industrial firms completed in the period 1979 to 1983 . The results indicate that merged firms have significant improvements in asset productivity relative to their industries after the merger, leading to higher post-merger operating cash flow returns. Sample furms maintain their capital expenditure and R\&D rates relative to their industries after the merger, indicating that merged firms do not reduce their long-term investments. There is a strong positive relation between post-merger increases in operating cash flows and abnormal stock retums at merger announcements, indicating that expectations of economic improvements underlie the equity revaluations of the merging firms.
\end{abstract}

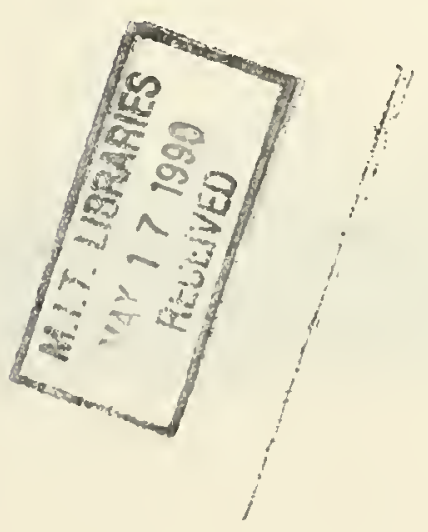




\section{DOES CORPORATE PERFORMANCE IMPROVE AFTER MERGERS?}

\section{Introduction}

This study examines the post-merger cash flow performance of acquiring and target firms, and explores the sources of merger-induced changes in cash flow performance. Our research is motivated by the inability of stock price performance studies to determine whether takeovers create real economic gains and to identify their sources.

There is near unanimous agreement that target stockholders benefit from mergers, as evidenced by the premium they receive for selling their shares. The stock price studies of takeovers also indicate that bidders generally break-even, and that the combined equity value of the bidding and target firms increase as a result of takeovers. These increases in equity values are typically attributed to some unmeasured source of real economic gains, such as synergy. But the equity value gains could also be due to capital market inefficiencies. For example, the equity value gains may simply arise from the creation of an over-valued security.

Previous studies have analyzed the stock price performance of unsuccessful takeovers to determine if the equity increases in takeovers are from real economic gains or capital market inefficiencies. 1 However, the studies of unsuccessful takeovers cannot distinguish between the real economic gains and the market inefficiency explanations. The fact that the stock prices of unsuccessful merger targets return to their pre-offer level is consistent with the loss of an anticipated premium -- whatever its source. The anticipation of real economic gains is observationally equivalent to market mispricing. It is, therefore, difficult to conceive of a pure stock price study that could resolve the ambiguity in the interpretation of the stock price evidence because of this inherent identification problem.

Stock price studies also cannot provide evidence on the sources of any merger-related

1 Dodd (1980), Asquith (1983), Dodd and Ruback (1977), Bradley, Desai and Kim (1983), and Ruback (1988). 
gains. Yet, differences of opinion about the source of the gains in takeovers underlies much of the public policy debate on their desirability. Gains from mergers could arise from a variety of sources, such as operating synergies, tax savings, transfers from employees or other stakeholders, or increased monopoly rents. Equity gains from only some of these sources are unequivocally beneficial at the social level.

Our approach is to use post-merger accounting data to directly test for changes in operating performance that result from mergers. 2 Our tests use accounting data collected from company annual reports, merger prospectuses, proxy statements and analysts' reports for 50 large mergers between U.S. public industrial firms which were completed in the period 1979 to 1983. We recognize that accounting data are imperfect measures of economic performance and that these data can be affected by managerial decisions. As we explain in section 2 , we use cash flow measures of economic performance to mitigate the impact of the financing of the acquisition and the method of accounting for the transaction. We also recognize that our cash flow variables measure period-by-period performance which is affected by firm-specific and industry factors. We therefore use industry performance as a benchmark to evaluate post-merger performance.

Results reported in Section 3 show that the merged firms have increases in post-merger operating cash flow performance relative to their industries. These increases arise from postmerger improvements in asset productivity. We find no evidence that the improvement in postmerger cash flows is achieved at the expense of the merged firms' long-term viability since the sample firms maintain their capital expenditure and R\&D rates relative to their industries. Our results differ from the findings reported by Ravenscraft and Scherer (1987), and Herman and Lowenstein (1988) who examine earnings performance after takeovers and conclude that merged

2 Three recent studies have examined earnings performance subsequent to management buyouts of corporations (Bull (1988), Kaplan (1990), and Smith (1990)). Our paper focuses on acquisitions of one public company by another either in a merger or a tender offer, rather than on management buyouts. 
firms have no post-takeover operating improvements. ${ }^{3}$

In section 4 we examine the relation between our cash flow measures of post-merger performance and stock market measures used in earlier studies. Improvements in operating cash flow returns in part explain the increase in equity values of the merging firms at the announcement of the merger. This indicates that the stock price reaction to mergers is driven by anticipated economic gains after the merger.

\section{Experimental Design}

\subsection{Sample}

We base our analysis on the largest 50 acquisitions during the period 1979 to 1983 . We limit the number of acquisitions studied to make the hand data collection tasks manageable. The largest acquisitions have several important advantages over a similarly sized random sample. First, if there are economic gains from a takeover, they are most likely to be detected when the target firm is large. Second, while the sample consists of a small fraction of the total number of acquisitions in the sample period, the total dollar value of the 50 firms selected accounts for a significant portion of the dollar value of takeover activity. ${ }^{4}$ Finally, it is less likely that the acquirers in the sample undertake equally large acquisitions prior or subsequent to the events, reducing the probability of confounding events.

The sample period (1979-83) is selected to focus on recent mergers and also to have sufficient post-merger performance data. To select the acquisition sample, we identify the 382

3 See Caves (1989) for a review of the studies that examine the ex post performance of merged firms.

4 The aggregate market value of equity of the 50 target firms in our sample one year prior to the acquisition is $\$ 43$ billion. 
merger-related delistings on the CRSP database in the sample period. The names of the acquirers are identified from the Wall Street Journal Index. The sample comprises acquisitions involving the 50 largest targets that satisfy the following two criteria: the acquirer is a US company which is listed on the NYSE or ASE, and the target and acquirer are not financial or regulated companies. Target firm size is computed from Compustat as the market value of common stock plus the book values of net debt and preferred stock at the beginning of the year prior to the acquisition. Acquisitions are deleted from the sample if the acquirers are non-US or private companies since post-acquisition financial information is not available for these mergers. Regulated (railroads and utilities) and financial firms are deleted because they are subject to special accounting and regulatory requirements, making them difficult to compare with other firms.

Table 1 reports descriptive statistics on the time distribution of the sample mergers, their industry distribution, and relative sizes of the target and acquiring firms. Panel A of the table shows that twelve of the fifty sample mergers are completed in 1981 and fourteen in 1983. The remaining 24 mergers are approximately evenly distributed over the other three sample years. Since the sample is clustered in time, the sample firms' post-merger performance is likely to be influenced by economy-wide changes. Our tests, therefore, control for these factors by comparing sample firms' performance with their corresponding industries'. Evidence in Panel B shows that the sample targets and acquirers represent a wide cross-section of Value Line industries. The target firms belong to 27 different industries; the acquiring firms come from 33 different industries. A list of target and acquirer firms in our sample and a description of their businesses is reported in an appendix.

Summary statistics on the relative sizes of the target and acquirer firms are reported in Panel $\mathrm{C}$ of Table 1. The sizes of targets and acquirers are measured by the book value of net debt 
(long-term debt, plus short-term debt, less cash and marketable securities) plus the market value of equity one year prior to the merger. The relative size of the two firms is the ratio of the size of the target to that of the acquirer. On average, the target firm is $42 \%$ of the assets of the acquirer, indicating that the acquisition is a significant economic event for the purchasing firms.

Descriptive statistics on the method of accounting, number of bidders, and method of payment, are reported in Table 2 for the 50 mergers. Panel A shows that the majority of transactions $(80 \%)$ are accounted for under the purchase method. Panel B shows that most of the acquisitions (70\%) are uncontested. Twenty percent are contested by two bidders (including the ultimate acquirer) and only ten percent of the transactions attracted more than two bidders. The distribution of the basis of payment in Panel C indicates that payments in the form of $100 \%$ cash, $100 \%$ stock and a combination of cash and stock are equally common.

\subsection{Performance Measurement}

We use pre-tax operating cash flows to measure improvements in operating performance. We define operating cash flows as sales, minus cost of goods sold, and selling and administrative expenses, plus depreciation and goodwill expenses. This measure is deflated by the market value of assets (market value of equity plus book value of net debt) to provide a retum metric that is comparable across firms. Unlike accounting return on book assets, our return measure excludes the effect of depreciation, goodwill, interest expense/income, and taxes. It is therefore unaffected by the method of accounting for the merger (purchase or pooling accounting) and/or the method of financing the merger (cash, debt, or equity). As discussed below, these factors make it difficult to compare traditional accounting returns of the merged firm over time and crosssectionally. 


\section{Effects of Purchase and Pooling Accounting}

The purchase method requires that the assets and liabilities of target firms be restated at their current market values. No such revaluation is permitted under the pooling method. Further, under the purchase method the acquirer records any difference between the acquisition price and market value of identifiable assets and liabilities of the target company as goodwill, and amortizes it. No goodwill is recorded under the pooling-of-interests method. Finally, for the first year of the merger, the purchase method consolidates results of the target with those of the acquirer from the date the merger took place; the pooling method consolidates results for the two firms from the beginning of the year regardless of when the merger took place.

The same transaction typically results in lower post-merger earnings under purchase accounting than under pooling. The purchase method increases depreciation, cost of goods sold, and goodwill expenses subsequent to the takeover. Also, in the year of the merger, earnings are usually lower under purchase accounting because it consolidates the target's earnings with the acquirer for a shorter period of time than pooling. The lower eamings reported under the purchase method are entirely due to differences in the method of accounting for the merger and not due to differences in economic performance. Furthermore, post-merger book assets under the purchase method will be larger than those under pooling because of the asset write-up under the purchase method. It is therefore misleading to compare post- and pre-merger accounting rates of retum for firms that use purchase accounting to infer whether there are economic gains from mergers. In our sample, $80 \%$ of the firms use the purchase method to account for the transaction.

Our operating cash flow performance measure --unlike earnings based performance measures -- is unaffected by depreciation and goodwill. It is comparable cross-sectionally and on 
a time-series basis when firms use different methods of accounting for the merger. We exclude the first year of the merger in our analysis because of the differences between the purchase and pooling methods in timing the consolidation of the target with the acquirer. Excluding the first year also mitigates the effect of inventory write-ups under the purchase method, since this inventory is usually included in cost of sales in the merger year. 5 Since the asset base in our return metric is the market value, rather than book value, of assets, it is also unaffected by the accounting method used to record the merger.

\section{Effects of Method of Financing Mergers}

Post-acquisition accounting earnings are also influenced by the method of financing the merger. Accounting income is computed after deducting interest expenses (the cost of debt), but before allowing for any cost of equity. Thus, if an acquisition is financed by debt or cash, its post-acquisition profits will be lower than if the same acquisition is financed by stock. Since the differences in earnings reflect the financing choice and not differences in economic performance, it is misleading to compare reported accounting earnings, which are computed after interest income and expense, for firms that use different methods of merger financing. Panel Cof Table 2 shows that cash and stock methods of financing are equally common in our sample. We use operating cash flows before interest expense and income from short-term investments deflated by the market value of assets to measure performance. This cash flow return is unaffected by the choice of financing.

5 Firms using the LIFO inventory valuation method expense the written-up inventory as inventory layers are depleted, making it difficult to determine when to adjust earnings for the effect of the write-up. We therefore do not make any adjustments for these firms. However, this is unlikely to lead to a serious downward bias in our earnings measure since LIFO inventory liquidations are relatively infrequent. 


\subsection{Performance Benchmark}

We add the accounting data of the target and bidding firms prior to the merger to obtain the proforma pre-merger performance of the combined firms. Comparing the post-merger performance to this pre-merger benchmark provides a measure of the change in performance. But some of the difference between pre-merger and post-merger performance could be due to economy-wide or industry factors. Hence, we use the industry-adjusted performance of the target and bidding firms as our primary benchmark to evaluate the post-merger performance. Industry-adjusted performance measures are calculated by subtracting the industry median from the sample firm value. The data for merging firms are excluded when calculating the industry median. Value Line industry definitions immediately prior to the merger are used for the target and acquirer in both the pre-merger and post-merger analysis. Industry data are collected from Compustat Industrial and Research files.

\subsection{Comparison with Prior Research}

We examine more recent mergers than those analyzed by previous studies of post-merger performance. Ravenscraft and Scherer's sample is from the period 1950 to 1977. While Herman and Lowenstein select firms that merge in the period 1975 to 1981 , they have limited post-merger data after 1981.

Neither Herman and Lowenstein, nor Ravenscraft and Scherer examine performance expectations prior to the merger, or restate earnings and assets for firms using purchase accounting, making it difficult to interpret their findings. Herman and Lowenstein do not adjust

their return on equity measure for differences in the method of financing the merger, and fail to control for the effect of common industry shocks on post-merger earnings performance. 
Ravenscraft and Scherer focus exclusively on lines of business. It is not obvious why gains from mergers would only be reflected in the acquired segments; synergies are just as likely to improve the performance of the other lines of business of the acquiring firms. They also use FTC line of business data which have several potential problems. Definitions of business segments may change systematically after mergers if acquirers restructure their operations. Results of tests using segment data reported to the FTC are also likely to be difficult to interpret since reporting firms have incentives to use accounting discretion to reduce the likelihood of antitrust suits by the FTC (see Watts and Zimmerman (1986)).

\section{Cash Flow Return Performance}

\subsection{Operating Cash Flow Returns before Industry Adjustments}

To construct the pre-merger performance benchmark, we aggregate the cash flow data for the target and acquiring firms to determine the proforma performance measures for the combined firm in each of the five years before the merger (years -5 to -1 ). Performance measures for the combined firms are weighted-averages of values for the target and acquiring firms separately, where the weights are the relative sizes of the two firms at the beginning of each year.

The pre-tax operating cash flows of the merged firm are computed for years 1 to 5 . Year 0 , the year of the merger, is excluded from the analysis for two reasons. First, many of the acquiring firms use the purchase accounting method, implying that in the year of the merger the two firms are consolidated for financial reporting purposes from only the date of the merger. Results for this year are therefore not comparable across firms or for industry comparisons. Second, year 0 figures are affected by one-time merger costs incurred during that year, making it difficult to compare them with results for other years. 
We deflate the operating cash flows by the market value of assets. Pre-tax operating cash flow returns are computed as the ratio of pre-tax operating cash flows during the year to the market value of assets at the beginning of the year. The market value of assets is recomputed at the beginning of each year to control for changes in the size of the firm over time. For premerger years the market value of assets is the sum of the values for the target and acquiring firms. The market value of assets of the combined firm is used in the post-merger years.

We exclude the change in equity values of the target and acquiring firms at the merger announcement from the asset base in the post-merger years. 6 This adjustment is important because an efficient stock market capitalizes the value of any expected improvement in equity prices at the merger announcement. If this equity revaluation is included in the asset base, the measured pre-tax operating cash flow returns will not show any abnormal increase, even when the merger results in an increase in operating cash flows. For example, consider an acquiring firm (company A) and a target (company $\mathrm{T}$ ) with annual operating cash flows of $\$ 20$ and $\$ 10$ respectively forever. Both firms have the same cost of capital (10\%), implying that their market values are $\$ 200$ and $\$ 100$ respectively. Therefore, a portfolio comprised of $A$ and $T$ has a market value of $\$ 300$ and cash flows of $\$ 30$, producing an annual return of $10 \%$. Suppose that when $A$ acquires $\mathrm{T}$ combined cash flows increase to $\$ 35$ per year. An efficient market capitalizes this $\$ 5$ improvement at $\$ 50$. If post-merger cash flow returns are computed as the ratio of post-merger cash flows (\$35) and post-merger assets including the premium $(\$ 350)$, measured performance will be identical to the pre-merger operating return for the portfolio of $\mathrm{A}$ and $\mathrm{T}(10 \%)$. There is no improvement in the measured cash flow return even though cash flows per year have increased by $\$ 5$. Our measure of performance is computed as the ratio of post-merger cash flows

6 The change in equity value of the target at the announcement of the merger is measured from five days before the first offer was announced (not necessarily by the ultimate acquirer) to the date the target was delisted from trading on public exchanges. The change in equity value of the acquirer is measured from five days before its first offer was announced to the date the target was delisted from trading on public exchanges. 
$(\$ 35)$ and post-merger assets excluding the asset revaluation $(\$ 350-\$ 50)$. This return measure (11.7\%) correctly reflects the improvement in operating performance after the merger.

Panel A of Table 3 reports median pre-tax operating cash flow returns for the merged firm in years -5 to -1 , and 1 to 5 . The median pre-tax operating returns range from $26 \%$ to $27.5 \%$ in the five years before the merger. After the merger, the median pre-tax operating returns are lower, ranging from $19 \%$ to $23 \%$ with a median annual value of $21.8 \%$ for the whole period. This indicates that post-merger performance is lower than the pre-merger benchmark.?

These data do not adjust for the impact of contemporaneous events on the merged firms' cash flow returns that are unrelated to the merger, and are therefore difficult to interpret. For example, since we deflate cash flows by the market value of assets, changes in equity values due to overall market movements will affect the measured returns over time. Equity values increased during most of our sample period. This may explain the decrease in the cash flow returns in the post-merger period. We focus on industry-adjusted performance measures because they incorporate any contemporaneous changes in the overall cash flow performance and equity values of the industry.

\subsection{Operating Cash Flow Returns after Industry Adjustments}

Industry-adjusted cash flow returns are the differences between values for the merged firm and its weighted-average industry median estimates. Prior to the merger industry values for the sample firms are constructed by weighting median performance measures for the target and acquiring firms' industries by the relative asset sizes of the two firms at the beginning of each

7 To calculate the sample median pre-tax operating cash flow return for years 1 to 5 , we first compute the median return in these years for each sample firm. The reported sample median is the median of these values. Sample median returns in the pre-merger period are calculated in the same way. 
year. In all of the post-merger years target and acquirer industry cash flow returns are weighted by the relative asset sizes of the two firms one year before the merger.

The industry-adjusted data reported in Panel B of Table 3 show that merged firms have superior pre-tax operating cash flow returns on assets relative to their industries' in the postmerger period. The industry-adjusted pre-tax operating return on assets for the merged firms is $2.7 \%$ in year $1,3.8 \%$ in year 2 , and $2.7 \%$ in year 3 , all significantly different from zero. Years 4 and 5 also exhibit superior performance relative to the industry, but these differences are not statistically significant. Overall, the annual median pre-tax return in the five post-merger years is $2.8 \%$. Stated differently, the merged firms' pre-tax operating returns in the post merger period are about $15 \%$ larger than their industries' returns. 8 In contrast, no superior industry-adjusted pre-tax operating cash flow returns occur in the five years before the merger; the median annual return is $0.4 \%$.

In Panel $\mathrm{C}$ of Table 3 we report the sample median difference in the industry-adjusted performance in the post- and pre-merger periods. 9 The improvement in industry-adjusted pre-tax operating cash flow returns in the post-merger years is confirmed; the median difference in industry-adjusted returns between the post- and pre-merger periods is $2.2 \%$, which is statistically reliable.

The industry-adjusted results are strikingly different from the operating cash flow returns

8 We calculate the percentage increase relative to the industry as $2.8 /(21.3-2.8)$.

9 To compute the sample median performance difference between the post- and pre-merger periods, we first calculate the median returns for each sample firm in the post- and pre-merger years. We then compute differences in the medians for each firm. The median of these pairwise differences is the sample median. 
before industry adjustment. The industry-adjusted results show a significant increase in postmerger performance and the unadjusted returns show a decrease in post-merger performance. Industry-adjusted returns are a more reliable measure of performance since they control for industry events unrelated to the merger. However, they are also confounded by two factors.

First, they are sensitive to the definitions of industries used in the analysis. To test whether the industry-adjusted results are sensitive to the particular industry definitions employed by Value Line, we use a market performance benchmark. We estimate the market index each year as the median operating cash flow return for all firms on the Compustat Industrial and Research tapes. The difference in the pre-merger and post-merger market-adjusted cash flow return for the sample firms is $4.5 \%$, confirming improvements in industry-adjusted performance.

Second, industry-adjusted returns can increase in the post-merger period even when cash flows remain constant or decline if the market value of sample firms' assets decline relative to their industries. Increased returns resulting from decreased asset values cannot be interpreted as evidence that there are economic gains from mergers. To test whether there are declines in postmerger market equity values of the sample firms relative to their industries, we compute the difference between the annual stock returns for the sample firms and their industries in years surrounding the merger. The industry-adjusted equity returns of the sample firms are insignificant in the post-merger period (as well as in the pre-merger period). The industryadjusted returns are: $0.4 \%$ in year $1,0.4 \%$ in year $2,0.2 \%$ in year $3,-3.7 \%$ in year 4 , and $3.7 \%$ in year 5. This implies that the improvements in post-merger industry-adjusted cash flow returns are due to increases in sample firms' operating cash flows rather than declines in their market values. 


\subsection{Components of Industry Adjusted Cash Flow Returns}

The improvements in pre-tax cash flow retums in the post-merger period can arise from a variety of sources. These include improvements in operating margins, increased asset productivity, or decreased labor costs. Altematively, they may be achieved by focusing on shortterm performance improvements at the expense of long-term viability of the firm. In this section we provide evidence on which of these sources contribute to the sample firms' post-merger cash flow return increases. The specific variables analyzed are italicized in the text and are defined in Table 4. The results are reported in Table 5.

\section{Operating Performance Changes}

The pre-tax operating cash flow return on assets can be decomposed into pre-tax cash flow margin on sales and asset turnover. Pre-tax cash flow margin on sales measures the operating cash flows generated per sales dollar. Asset turnover measures the sales dollars generated from each dollar of investment in assets. The variables are defined so that their product equals the pre-tax operating cash flow return on assets.

The results in Table 5 suggest that the increase in industry-adjusted pre-tax-operating retums is attributable to an increase in asset turnover, rather than an increase in pre-tax operating margins. In years -5 to -1 the merged firms have industry-adjusted median asset turnover of -0.3 , implying that they generated thirty cents less sales than their competitors for each dollar of assets. The merged firms show a significant improvement in their industry-adjusted asset turnover ratios in the post-merger period. In years 1 to 5 the industry-adjusted asset turnover is 0.1 , indicating that the sample firms generate ten cents more sales than their industry counterparts for each dollar of assets. The sample median difference in asset tumovers between these periods is 0.2 , which is statistically significant. The merged firms also have higher pre-tax operating 
margins on sales than their industries in the post-merger years. But these cannot be attributed to the merger itself, since operating margins of the merged firms are also higher than those of their industries in the pre-merger period. 10 The difference between the pre-and post-merger industry adjusted operating margin is insignificant. The absence of changes in operating margins suggest that the post-merger cash flow improvements are not due to increases in monopoly rents. Rather, merged firms seem to use their assets more productively.

Mergers also provide the acquirer with an opportunity to renegotiate explicit and implicit labor contracts to lower labor costs and achieve a more efficient mix of capital and labor (see Schleifer and Summers (1988)). Because we are unable to obtain sufficient data on wages directly, we examine employee growth rates and pension expense per employee to analyze changes in labor costs in years surrounding the mergers.

The median number of employees declines in each of the post-merger years. Overall, the industry-adjusted employee growth rate is significantly less than in the pre-merger period. 11 There is also evidence of a decline in pension expense per employee after the merger. Before the merger the sample firms have a significantly higher pension expense per employee than their industries. After the merger the pension expense of the merged firms is reduced to the same level as the industry. There are two ways to view these findings. One interpretation is that mergers are followed by improvements in operating efficiency through reduced labor costs. Alternatively, mergers lead to a wealth redistribution between employees and stockholders through

10 Prior to the merger, the higher operating margins are primarily due to higher industry-adjusted margins by acquirers. Targets do not show higher operating margins than their industries in these years.

11 Wages per employee for the merged firms also decline relative to the industry after the merger. However, this finding should be interpreted with caution since only a small number of firms report information on wages. 
renegotiations of explicit and implicit employment contracts. Whatever the explanation, the magnitude of labor cost reductions in the post-merger period does not appear to be large since there are no significant changes in the post-merger operating margins.

\section{Investment Policy Changes}

Since our analysis is limited to only five years after the merger, we cannot provide direct evidence on cash flows beyond this period. To assess whether the merged firms focus on shortterm performance improvements at the expense of long-term investments, we examine their capital outloys, and research and development (R\&D). These expenditure patterns are reported in Table 5. The median capital expenditures as a percentage of assets is $15 \%$ in the pre-merger period and $11 \%$ in the post-merger years. The median R\&D expense is $2.1 \%$ of assets in years -5 to -1 , and $2.4 \%$ in years 1 to 5 . The capital expenditures and R\&D of the sample firms are not significantly different from those of their industry counterparts in either the pre- or the postmerger periods.

Asset sales is another area where merged firms can potentially change their investment policies. It is possible that post-merger improvements in asset tumover arise from the sale of assets with low turnover. We therefore examine asset disposals in the pre- and post-merger years. Statistics on asset sales as a percent of the market value of assets are reported in Table 4. The median asset sales for the merged firms are $1.6 \%$ and $0.9 \%$ of assets in the pre- and postmerger periods respectively. The merged firms have significantly higher asset sales rates than their industry counterparts both before and after the merger. However, there is no significant difference in industry-adjusted asset sales before and after the merger. Further, asset sales in all years are small in magnitude relative to capital expenditures or the market value of total assets. 
In summary, we find that merged firms have significant improvements in cash flow operating retums in the five years following mergers. These improvements come from increased asset productivity. There is no evidence of increased asset sales, or decreased capital expenditures or R\&D following mergers.

\section{Relation Between Cash Flow And Stock Price Performance}

Our post-merger data on cash flow performance is consistent with the hypothesis that the stock market revaluation of merging firms at merger announcements reflects expected future improvements in operations. A more powerful test of this hypothesis is to correlate the mergerrelated stock market performance and the post-merger cash flow performance. If the stock market capitalizes these improvements, there should be a significant positive correlation between the stock market revaluation of merging firms and the actual post-merger cash flow improvements.

\section{Stock Returns at Merger Announcements}

Market-adjusted stock returns for the target and acquirer at the announcement of the merger are reported in Panel A of Table 6.12 Returns for the target are measured from five days before the first offer was announced (not necessarily by the ultimate acquirer) to the date the target was delisted from trading on public exchanges. Returns for the acquirer are measured from five days before its first offer was announced to the date the target was delisted from trading on public exchanges. Similar to findings reported by earlier studies, target shareholders earn large positive returns from mergers (mean $45.6 \%$, and median $41.8 \%$ ), and acquiring stockholders earn insignificant returns.

12 Risk-adjusted returns, computed using pre-merger-announcement market model estimates, are similar to the market-adjusted retums reported in the paper. 
We also compute the aggregate market-adjusted return for the two firms in the merger announcement period. This return is the weighted average of the market-adjusted returns for the target and acquirer, where the weights are the relative market values of equity of the two firms prior to the merger announcement period. The mean aggregate return, reported in Panel A of Table 6 , is $9.1 \%$, and the median is $6.6 \%$. Both these values are significantly different from zero. These findings are consistent with those of Bradley, Desai, and Kim (1988).

Relation Between Announcement Returns and Post-Merger Cash Flow Improvements

Our tests examine whether the change in equity values at merger announcements can be explained by cash flow improvements in the post-merger period. In Section 3 we measured postmerger performance using cash flow return on assets whereas the merger announcement returns computed above are return on equity. Therefore, before we correlate announcement returns and cash flow improvements, we compute asset returns at merger announcements from equity returns to ensure that the anticipated gains from mergers and ex post measured gains are comparable.

Asset returns at the merger announcement $(\Delta \mathrm{V} / \mathrm{V})$ are weighted averages of returns to equity $(\Delta \mathrm{E} / \mathrm{E})$ and debt $(\Delta \mathrm{D} / \mathrm{D})$ :

$$
\frac{\Delta V}{V}=\frac{(\Delta E)}{E} \frac{E}{V}+\frac{(\Delta D)}{D} \frac{D}{V}
$$

Assuming that the value of debt does not change at takeover announcements, asset returns equal the equity announcement returns multiplied by the equity-to-assets ratio $(E / V) .13$ We use leverage at the beginning of the year of the takeover announcement to compute the equity-to-asset ratio.

13 A number of studies including Asquith and Kim (1982), report evidence consistent with this assumption. 
Summary statistics on the estimated asset returns for the target firms, acquiring firms, and combined firms are reported in Panel B of Table 6. The mean and median asset returns for the targets are $40.6 \%$ and $32.5 \%$, and for the combined firms are $8.8 \%$, and $5.2 \%$. The asset returns for the bidding firm are insignificant.

The hypothesis that merger-induced abnormal retums reflect the capitalized value of future cash flow improvements implies:

$$
\Delta \mathrm{V}=\mathrm{PV}(\mathrm{CF})
$$

where $\Delta \mathrm{V}$ is the change in the market value of assets at the merger announcement, $\mathrm{PV}$ is the present value operator, and $C F$ is the vector of cash flow improvements. Equation (2) can be converted to a returns model by dividing both sides of the equation by $\mathrm{V}$ :

$$
\Delta \frac{\mathrm{V}}{\mathrm{V}}=\frac{\mathrm{PV}(\mathrm{CE})}{\mathrm{V}}
$$

Consistent with equation (3), we estimate the following cross-sectional regression:

$$
\operatorname{ARET}_{i}=\alpha+\beta \operatorname{CFRET}_{i}+\varepsilon_{i}
$$

Where ARET is the combined firms' measured abnormal asset return at the merger announcement (unlevered abnormal equity returns) and CFRET is the median annual industry-adjusted pre-tax operating cash flow return in the post-merger period.

The valuation model (equation (3)) does not have a constant, implying that the intercept in (4) should equal zero. Since ARET is the capitalized value of future cash flow retum improvements, and CFRET is the pre-tax cash flow retum improvement per year, the slope in (4) equals the present value factor at the pre-tax capitalization rate. For example, if the pre-tax capitalization rate is $20 \%$, the slope coefficient would be 5 if the improvements are perpetual, and 2.99 if the improvements last for five years. For a capitalization rate of $30 \%$, these coefficients 
would be 3.33 and 2.44 respectively.

The estimates of regression equation (4) are reported in Panel A of Figure 1. The regression has an $\mathrm{R}^{2}$ of $21 \%$, implying a cross-sectional correlation of 0.46 between the asset returns at the merger announcement and the realized improvements in cash flow returns. While the estimated slope coefficient is positive and statistically reliable, its magnitude is only 0.96 , implying a very high discount rate. Also, the intercept is statistically significant. However, these regression estimates are likely to be biased since the operating cash flow returns have substantial measurement error. This measurement error results in a downward bias in the estimated slope coefficient and an upward bias in the estimated intercept (see Johnston (1972)).

To provide a bound on the coefficient estimates, we reverse the dependent and independent variables in (4) and estimate the following regression equation :

$$
\text { CFRET }_{i}=\gamma+\lambda \text { ARET }_{i}+v_{i}
$$

The results are reported in Panel B of Figure 1. The estimated slope coefficient in equation (5) is 0.22 . That is, the market capitalization rate is $22 \%$ if the improvements are a perpetuity. This estimate corresponds to a slope coefficient value of 4.55 in equation (4). The estimated intercept in equation (5) is insignificant. These regression estimates are more in line with the predicted values. 14

Since the regression analysis is affected by measurement error, we also compute a back-

14 Specification tests are conducted for regression equations (4) and (5) to assess whether the residuals are homoskedastic (see White (1980)), and normally distributed. We cannot reject the hypotheses that the residuals are homoskedastic and normally distributed at the 0.05 level. Belsley, Kuh and Welsch (1980) diagnostics for the effect of extreme observations on the coefficients, and for multicollinearity indicate that the reported estimates are not influenced by extreme observations. Finally, we estimate Spearman Rank Correlation coefficients between the variables in the regression. The correlation is 0.45 and is significant at the 0.01 level. 
of-the-envelope estimate of the merger announcement asset return implied by the sample median cash flow improvement. The data in Table 3 indicate that the merged firms' median annual pretax operating cash flow return on assets in the post-merger period is about $2.2 \%$ larger than their industries' return. To convert this to a rough estimate of the value change, we assume that the risk of the improved performance equals the risk of an average security. We use an $8 \%$ risk premium along with a $10 \%$ risk free rate for an $18 \%$ before-tax cost of capital. If the cash flow gain is treated as a perpetuity, the implied increase in the asset value is $12 \%$. If the increased performance lasts for just five years, the asset value increase is about $6.6 \%$. The actual mean and median asset returns at the merger announcement reported in Table 6 are consistent with these rough estimates.

In summary, the abnormal equity returns for the combined firms at the merger announcement are broadly consistent with the value increases implied by the post-merger cash flow retum increases.

\section{Discussion}

Our finding that cash flows increase following mergers advances the debate on mergers from whether there are cash flow changes after these transactions to why these cash flow improvements occur. The improvements in sample firms' cash flow returns are primarily a result of increased asset productivity. The reported post-merger gains cannot be attributed to tax benefits, since the cash flow returns are pre-tax. They cannot be attributed to increased monopoly rents since there is no increase in post-merger sales margins. While there is some evidence that gains come at the expense of labor, reduced labor costs do not significantly increase sample firms' profitability. Finally, there is no decrease in capital outlays and R\&D expenditures, or increase in asset sales after the merger, indicating that merged firms do not 
reduce their long-term investments.

Our findings raise two interesting questions. First, are the increases in cash flow returns and asset productivity caused by the merger, or would they have occurred even without a merger? Mergers can lead to increased asset productivity if sub-optimal policies pursued by the target or the acquirer prior to the merger are eliminated, or if they provide new opportunities for using existing resources of the merging firms. In contrast, if mergers arise from undervaluation of the target firms by the stock market, there will be improvements in cash flows whether or not there is a merger. Acquirers that anticipate the cash flow improvements will pay a premium to acquire the targets.

A second interesting question is what are the economic factors that explain the crosssectional variation in post-merger cash flow changes? While there is an improvement in cash flow performance on average, a quarter of the sample firms have negative post-merger cash flow changes. These firms may have performed poorly because of bad luck. Alternatively, there may have been systematic business and managerial reasons which led to these outcomes.

These questions, which have important managerial and public policy implications, can only be answered by developing structural models of how mergers improve cash flows. We do not attempt to undertake such an ambitious exercise in this paper. However, we do provide some preliminary evidence and suggest directions for future research.

One popular structural model of how mergers improve cash flows is that they provide opportunities for economies of scale and scope, synergy, or product market power. This implies that mergers by firms that have related products or production will show greater cash flow 
improvements than mergers between unrelated firms. 15 We examine this proposition by classifying our sample firms as related or unrelated, and by comparing the average post-merger cash flow improvements of the two groups. We classify mergers between firms with the same Value Line industry definition as related. The results indicate that there are no differences in the post-merger industry-adjusted operating cash flow returns between related and unrelated mergers.

We also classify mergers into related and unrelated categories by examining the reasons for undertaking mergers stated by the sample firms' managers in the merger prospectuses. The potential to exploit product similarities or other associations is the most commonly stated reason. For example, the managers of Maryland Cup and Fort Howard Paper Co. (both in the paper products industry) expected the merger to create "a number of new business opportunities as a result of the compatibility of the two companies' businesses and customers." In addition, they argued that "Maryland Cup could benefit from Fort Howard's production experience." The second most frequently stated reason for merging is to reduce earnings volatility, as in the Raytheon / Beech Aircraft merger. The managers of Raytheon anticipated that the acquisition would "provide Raytheon with additional stability through product diversification as well as a better balance between commercial and government-generated sales and earnings." We examine whether there is a difference in post-merger cash flow returns for sample mergers undertaken to exploit synergies and other mergers, and find no difference between the two groups.

The relation between the merging firms' businesses does not appear to be the sole determinant of post-merger performance. For example, Pan Am and National Airlines were both in the airline business, yet their merger was unsuccessful. Pan Am expected the acquisition to expand the domestic feeder routes to its international flights, providing a competitive edge over

15 Kaplan and Weisbach (1990) find that acquirers of firms in unrelated businesses are more likely to later divest these targets than acquirers of related businesses. 
other international carriers. However, the company did not have the expertise to run a domestic airline, especially in the competitive conditions after deregulation. Further, Pan Am later divested its Pacific routes, reducing the value of the National's domestic services to the west coast.

Given the complexity and heterogeneity of reasons for mergers, we believe that large sample studies are unlikely to provide significant new insights into the structural factors that influence the outcomes of mergers. A promising approach is to examine a smaller number of mergers in greater detail. These clinical studies will provide valuable evidence on the mechanisms through which mergers increase cash flows, and will be fruitful avenues for future research.

\section{Summary}

This paper examines the post-acquisition operating performance of merged firms using a sample of the 50 largest mergers between U.S. public industrial firms completed in the period 1979 to 1983 . We find that merged firms have significant improvements operating cash flow returns after the merger, resulting from increases in asset productivity relative to their industries. These cash flow improvements do not come at the expense of long-term performance, since sample firms maintain their capital expenditure and $R \& D$ rates relative to their industries after the merger. There is a strong positive relation between post-merger increases in operating cash flows and abnormal stock returns at merger announcements, indicating that expectations of economic improvements underlie the equity revaluations of the merging firms. 


\section{REFERENCES}

Asquith, Paul, 1983, Merger bids, uncertainty, and stockholder returns, Journal of Financial Economics, 11, 51-84.

Asquith, Paul, and E. Han Kim, 1982, The impact of merger bids on participating firms' security holders, Joumal of Finance 37, 1209-1228.

Bradley, Michael, Anand Desai and E. Han Kim, 1983, The rationale behind interfirm tender offers: Information or synergy?, Journal of Financial Economics, 11, 183-206.

Bradley, M., A. Desai and E. Kim, 1988, Synergistic gains from corporate acquisitions and their division between the stockholders of target and acquiring firms, Journal of Financial Economics, 21, 3-40.

Bull, I., 1988, Management Performance and leveraged buyouts: An empirical analysis, Unpublished paper, University of Illinois at Urbana-Champaign.

Caves, Richard E., 1989, Effect of Mergers and Acquisitions on the Economy: An Industrial Organization Perspective.

Dodd, Peter, 1980, Merger proposals, management discretion and stockholder wealth, Journal of Financial Economics,8, 105-138.

Dodd, Peter and Richard Ruback, 1977, Tender offers and stockholder returns: An empirical analysis, Journal of Financial Economics, 5, 351-374.

Herman, E. and L. Lowenstein, 1988, The efficiency effects of hostile takeovers, in J. Coffee Jr., L. Lowenstein and S. Rose-Ackerman, eds., Knights, raiders and targets: The impact of the hostile takeover, (Oxford University Press, New York, NY).

Jensen, M. and R. Ruback, 1983, The market for corporate control: The scientific evidence, Journal of Financial Economics, 11, 5-50.

Johnston, J., 1972, Econometric Methods, Second Edition, (McGraw-Hill, New York, NY).

Kaplan, S., 1990, The effects of management buyouts on operating performance and value, Journal of Financial Economics, forthcoming.

Kaplan, S. and M. Weisbach, 1990, Acquisitions and diversification: What is divested and how much does the market anticipate? Working paper, University of Chicago.

Ravenscraft, D., and F. M. Scherer, 1987, Mergers, selloffs, and economic efficiency, (Brookings, Washington, D.C.)

Ruback, R., Do target shareholders lose in unsuccessful control contests?, in Corporate Takeovers: Causes and Consequences, National Bureau of Economic Research, 1988.

Schleifer, A. and L. Summers, 1988, Breach of trust in hostile takeovers, in Corporate 
Takeovers: Causes and Consequences, National Bureau of Economic Research.

Smith, A., 1990, Corporate ownership structure and performance: The case of management buyouts, Journal of Financial Economics, forthcoming. 


\section{Table 1}

Descriptive statistics on time distribution of mergers, industry distribution and relative asset sizes for 50 acquiring and 50 target firmsa

\section{Panel A: Distribution of Merger Years}

Number of firms

1979

1980

1981

1982

1983

Total

\section{9}

6

12

9

14

50

\section{Percent of firms}

18

12

24

18

28

100

Panel B: Distribution of Target and Acquiring Firms' Industries

\section{Target firms}

Number of industries

Industries with 1 firm

Industries with 2 firms

Industries with 3 firms

Industries with 4+ firms
15

8

2

2
Acquiring firms

33

22

9

0

2

6

Panel C: Relative Asset Sizes of Target and Acquirers

Mean

$42.0 \%$

First quartile

Median

Third quarter

a The sample mergers are the largest acquisitions completed in the period 1979 to 1983 between public non-financial and non-utility U.S. firms. Acquisition size is measured by the market value of common stock plus the book values of debt and preferred stock for the target firm at the beginning of the year prior to the acquisition. The merger year is the year in which the merger was completed. Relative asset size is the target's size as a percent of the size of the acquiring firm, where asset size is the market value of common stock plus the book values of debt and preferred stock at the beginning of the year prior to completion of the acquisition. Industries are based on Value Line industry definitions prior to the merger. 


\section{Table 2}

Summary statistics on merger transaction accounting methods, number of bidders, method of payment, and merger type for 50 mergers in the period 1979 to 1983.

Panel A: Distribution of firms by method of accounting for merger

Accounting method

Purchase method $78 \%$

Pooling of interests

Panel B: Distribution of firms by number of bidders

Number of bidders

One bidder $76 \%$

Two bidders

12

Three bidders

Four or more bidders

Panel C: Distribution of firms by merger method of poyment

\section{Method of payment}

$100 \%$ stock

$100 \%$ cash

Cash and stock 


\section{Table 3}

Firm and industry-adjusted median annual operating pre-tax cash flow return on assets for 50 combined target and acquirer firms' in years surrounding merger a

\begin{tabular}{|c|c|c|c|}
\hline $\begin{array}{l}\text { Year relative } \\
\text { to merger }\end{array}$ & $\begin{array}{l}\text { Firm } \\
\text { median }\end{array}$ & $\begin{array}{l}\text { Industry- } \\
\text { adjusted } \\
\text { median }\end{array}$ & $\begin{array}{l}\text { Number of } \\
\text { observations }\end{array}$ \\
\hline
\end{tabular}

Panel A: Pre-merger performance:

$\begin{array}{llll}-5 & 26.0 \% & -0.3 \% & 49 \\ -4 & 27.3 & -0.4 & 49 \\ -3 & 27.4 & -0.2 & 49 \\ -2 & 27.5 & 0.4 & 49 \\ -1 & 26.8 & 0.6 & 46\end{array}$

Median annual performance for years -5 to -1

$25.9 \%$

$0.4 \%$

50

Panel B: Post-merger performance:

$\begin{array}{llll}1 & 22.2 \% & 2.7 \% \mathrm{~b} & 48 \\ 2 & 23.0 & 3.8^{\mathrm{b}} & 47 \\ 3 & 21.2 & 2.7 \mathrm{c} & 45 \\ 4 & 19.0 & 2.3 & 41 \\ 5 & 19.6 & 2.4 & 30\end{array}$

Median annual performance for years 1 to 5

Panel C: Difference between pre-and post-merger performance

Median annual difference between performance in years -5 to -1 and 1 to 5

$-4.8 \% \quad 2.2 \% \mathrm{c}$

48

a The mergers are completed in the period 1978 to 1983. Pre-tax operating cash flow return on assets are sales minus cost of goods sold, minus selling and adminstrative expenses, plus depreciation as a percent of the market value of assets at the beginning of the year (the market value of common stock plus the book values of debt and preffered stock. Industry-adjusted values of these variables are computed for each firm and year as the difference between the firm value in that year and the median value for other firms in the same industry (as defined by Value Line in year -1). Prior to the merger, performance measures for the merged firm are weighted averages of target and acquirer values, with the weights being the relative asset values of the two firms. Performance measures for the merged firm's industry in the pre-merger (post-merger) period are weighted averages of target industry and acquirer industry medians, with the weights being the relative asset values of the two test firms in each year (in year -1 ).

b Significantly different from zero at the $1 \%$ level.

c Significantly different from zero at the $5 \%$ level. 


\section{Table 4}

Definitions of variables used to analyze actual performance of 50 targets and 50 acquirers in years surrounding mergers

Variable

Definition

\section{A. Operating Performance}

Pre-tax operating margin

Asset tumover

Employee growth rate

Pension expense/employee

B. Investment Policy

Capital expenditure rate

Asset sale rate

$R \& D$ rate
Earnings before depreciation, interest, and taxes as a percent of sales

Sales divided by market value of assets at beginning of year (the market value of common equity plus the book values of debt and preferred stock)

Change in number of employees as a percent of number of employees in the previous year

Pension expense per employee

Capital expenditures as a percent of the market value of assets at beginning of year

Asset sales as a percent of the market value of assets at beginning of year

Research and development expenditures as a percent of the market value of assets at beginnig of year 


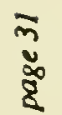

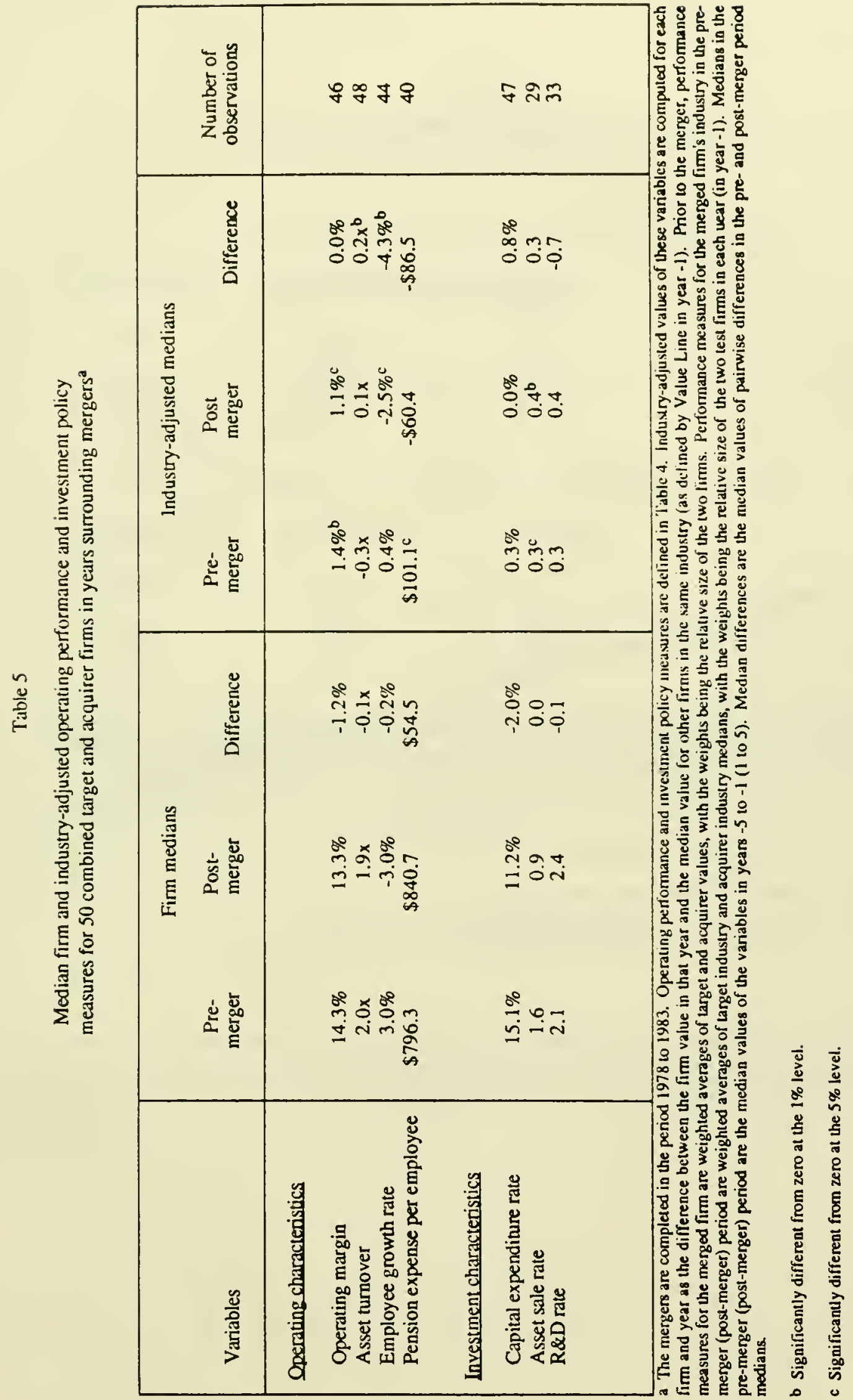


Table 6

Equity and asset returns at merger announcements for 50 target and acquiring firms merging in the period 1979 to $1983^{\text {a }}$

Panel A: Distribution of equity returns at merger announcement

Target equity Acquiring equity Combined equity

Mean

$45.6 \%^{b}$

$-2.2 \%$

$9.1 \%^{b}$

First quartile

Median

Third quartile

$21.2 \%$

$-16.6 \%$

$-2.9 \%$

$41.8 \%^{b}$

$-3.6 \%$

$64.1 \%$

$3.4 \%$

$6.6 \%^{\mathrm{b}}$

$16.7 \%$

Panel B: Distribution of asset returns at merger announcement

\section{Target firms Acquiring firms Combined firms}

Mean

First quarile

Median

Third quartile
$40.6 \%$ b

$0.6 \%$

$19.0 \%$

$32.5 \%$ b

$55.0 \%$
$-9.3 \%$

$-2.2 \%$

$6.1 \%$
$8.8 \%$ b

$-2.3 \%$

$5.2 \%^{\mathrm{b}}$

$15.1 \%$

a The unexpected merger announcement retum is the sum of the market-adjusted change in equity value for the target and acquirer in the merger announcement period as a percentage of the sum of the pre-merger equity values for the two firms. Post-merger performance measures for each firm are averages of values in the five years after the merger. For definitions of performance characteristics see Table 3 . Industry-adjusted values of these variables are computed for each firm and year as the difference between the furm value in that year and the median value for other firms in the same Value Line industry.

b Significantly different from zero at the 18 level using a two tailed test.

c Significantly different from zero at the $5 \%$ level using a two tailed test.

d Significantly different from zero at the $10 \%$ level using a two tailed test. 
Figure 1

Panel A: ARET $_{\mathrm{i}}=\gamma+\lambda$ CFRET $_{\mathrm{i}}+v_{\mathrm{i}}$

\author{
Unexpected asset \\ returns (ARET)
}

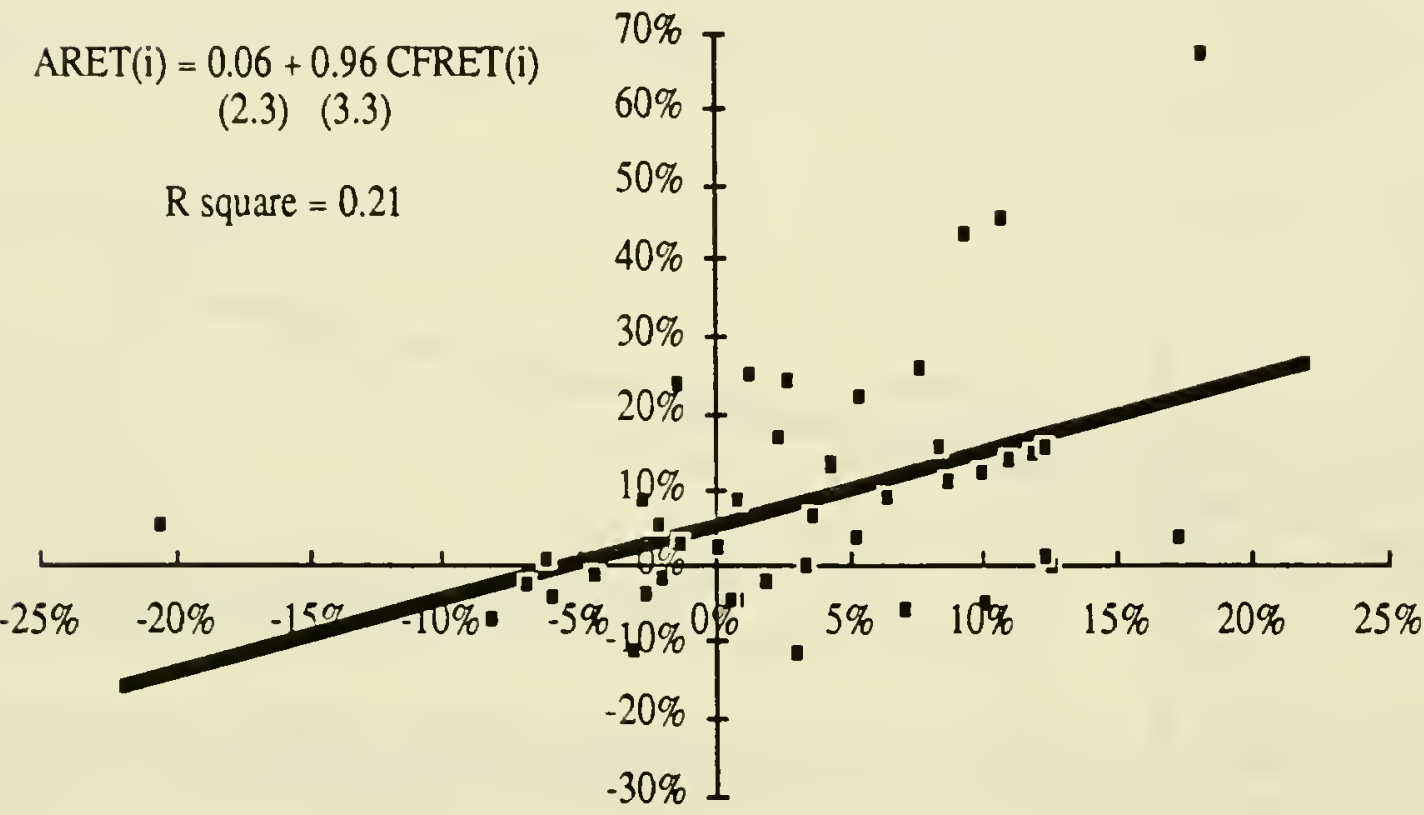

Median post-merger industry-adjusted pre-tax cash flow returns (CFRET)

a The mergers are completed in the period 1978 to 1983 . The unexpected asset return is computed by unlevering the combined equity announcement returns for the target and acquiring firms. The combined equity return for these firms is the sum of the market-adjusted change in equity value for the target and acquirer in the merger announcement period as a percentage of the sum of the pre-merger equity values for the two firms. Post-merger industry-adjusted cash flow returns are defined in table 3. 
Figure 1 continued

Relation between median post-merger industry-adjusted cash flow returns and unexpected asset retums at merger announcements for 50 merging firms ${ }^{a}$

Panel B: CFRET $_{\mathrm{i}}=\alpha+\beta$ ARET $_{\mathrm{i}}+\varepsilon_{\mathrm{i}}$

Median post-merger industry-adjusted

pre-tax cash flow returns (CFRET)

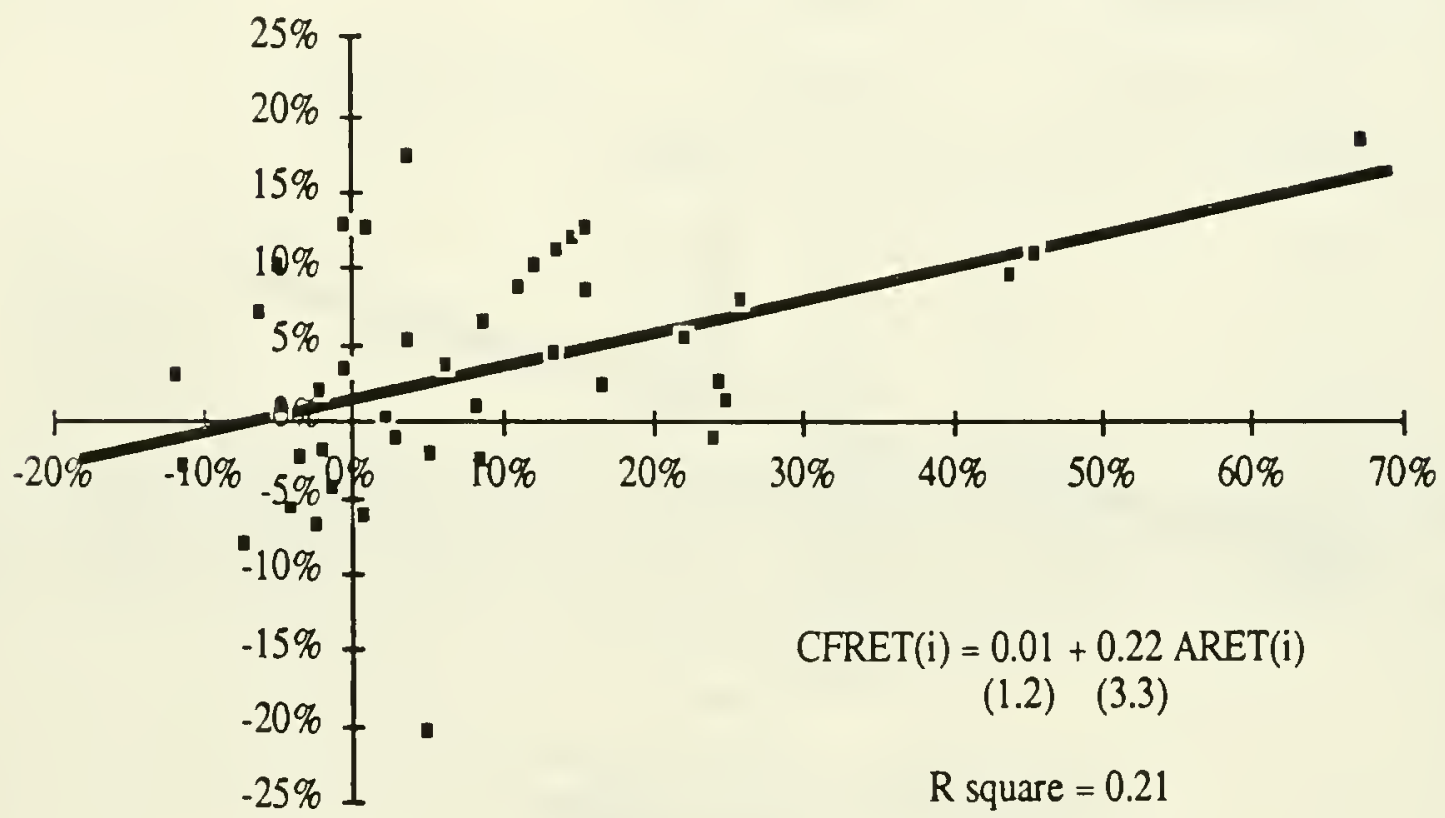

Unexpected asset

retums (ARET) 


\section{Appendix Acquiring/Target Firms and their Industries}

\section{American Medical Intemational /Lifemark}

American Medical owns and operates proprietary hospitals and other health care businesses, and offers medical-technical support (including diagnostic, cardio-pulmonary, and physical therapy services, and management consulting services). Lifemark owns and manages general hospitals, and provides cardio-pulmonary, physical therapy, pharmacy, and clinical laboratory services.

\section{Anheuser-Busch Companies / Campbell Taggart Inc.}

Anheuser-Busch is the world's largest brewer of beer. Campbell Taggart's business is baking and distributing bread, rolls, crackers, cake and other sweet products, and food products.

3. Associated Dry Goods / Caldor Inc.

Associated Dry Goods operates general department stores in 25 states. Caldor operates 65 promotional discount department stores in five states.

\section{Avon Products Inc. / Mallinckrodt}

Avon is the world's largest manufacturer of cosmetics and toiletries, and also sells costume jewellery and ceramics. Mallinckrodt develops and manufactures fine chemicals, drugs and other health care products, and chemicals for the food, cosmetics, laboratory, petrochemical and printing industries.

\section{Best Products / Modern Merchandising Inc.}

Best and Modern Merchandising are both catalog showroom retailers.

6. Brown-Forman Distillers / Lenox Inc.

Brown-Forman manufactures a wide variety of alcoholic beverages. Lenox operates produces home furnishings (including china and crystal), and personal use products (including jewelry and luggage).

\section{Burroughs Corp./ Memorex Corp.}

Burroughs is a major participant in the data processing and business computer equipment industry. Memorex develops, manufactures, markets and services a wide range of computer peripheral equipment systems, and products employed in the recording, retrieval, communication, and storage of information.

\section{Coca Cola Co./ Columbia Pictures Industries Inc.}

Coca-Cola is the largest manufacturer and distributor of soft drink concentrates and syrups in the world. The company also manufactures citrus, coffee, tea, wine and plastic products. Columbia Pictures produces and distributes theatrical motion pictures, television series and features, amusement games, and commercials.

\section{Con Agra Inc./Peavey Co.}

Con Agra is a diversified food processor engaged in agriculture (agricultural chemicals, formula feed, and fertilizers), grain (flour, by-products, and grain and feed merchandising) and food (frozen foods, broiler chicken, eggs, seafood, and pet products) industries. Peavey is also a diversified food processor and retailer engaged in grain merchandising, food processing (flour, bakery mixes, and jams), and operating specialty retail stores, . 


\section{Cooper Industries /Gardner-Denver}

Cooper is a diversified, international corporation which produces consumer and industrial tools, aircraft services, mining and construction, and energy services. Gardner-Denver makes portable and stationary air compressors, drilling equipment for above- and underground, and air-operated tools.

\section{Dart Industries /Kraft Inc.}

Dart is diversified company that manufactures and markets consumer products, including Tupperware containers, Duracell batteries, and West Bend appliances. Kraft manufactures food products and markets them to retail, industrial and food service customers.

\section{Diamond Shamrock / Natomas Co.}

Diamond Shamrock is a domestic integrated oil and gas company with interests in coal and chemicals. Natomas is principally engaged in petroleum exploration and production.

\section{E. I. Du Pont de Nemours / Conoco Inc.}

Du Pont manufactures diversified lines of chemicals, plastics, specialty products, and fibers. Conoco is engaged in the exploration, production, and transportation of crude oil, coal, and natural gas; petroleum refining; and the production, processing and transportation of chemicals.

\section{Eaton Corp./ Cutler-Hammer Inc.}

Eaton is engaged in technologically related businesses in areas of transportation, materials handling, industrial automation, security, construction, agriculture and consumer durables. Cutler-Hammer designs and manufactures electronic and electrical components and system for industrial, aerospace, air traffic control, semiconductor, housing, and consumer markets.

\section{Exxon Corp./ Reliance Electric Co.}

Exxon is engaged in the exploration, production, and transportation of crude oil and natural gas; and the production and transportation of petroleum and chemicals. Reliance develop, manufacture, and servicing a broad line of industrial equipment, including electric motors and drives, mechanical power transmission components, industrial and retail scales and weighing systems, and telecommunications equipment.

\section{Fairchild Industries / VSI Corp.}

Fairchild produces military aircraft and parts, commercial aircraft and parts, spacecraft and parts, and domestic communications systems. VSI is a diversified manufacturer of a wide range of precision metal products (including fastening systems for aircraft and missiles, steel mod bases for the plastics industry, door knobs, stainless steel cabinets, and building hardware.

\section{Fluor Corp/St. Joe Minerals Corp.}

Fluor designs, engineers, procures and constructs complex manufacturing plants, processing plants, and related facilities for energy, natural resources and industrial clients. St. Joe is a diversified producer of natural resources (principally coal, lead, gold, oil and gas, zinc, silver and iron ore).

\section{Fort Howard Paper Co./Maryland Cup Corp.}

Fort Howard manufactures a broad line of disposable sanitary paper products, principally table napkins, paper towels, toilet tissue, industrial and automotive wipes, and boxed facial tissues. Maryland Cup manufactures a variety of single use paper and plastic products for food and beverage service, including plates, cups, bowls, cutlery, drinking straws and toothpicks. 


\section{Ereeport Minerals Co./McMoran Oil \& Gas Co}

Freeport Minerals is a diversified company engaged in exploration and development of natural resources, including agricultural minerals, oil and gas, uranium, oxide and kaolin. McMoran is engaged in the acquisition, exploration and development of oil and gas properties, and the production and sale of oil and natural gas.

\section{Gannett Co. Inc/ Combined Communications Corp.}

Gannett and its subsidiaries publish daily newspapers. Combined Communications Corporation is engaged in television and radio broadcasting, outdoor advertising and newspaper publishing.

\section{General Foods Corp./Oscar Mayer \& Co. Inc.}

General Foods is a leading processor of packaged grocery products. Oscar Mayer operates in the meat packing and processing industry.

\section{Genstar Ltd./ Flintkote Co.}

Genstar manufactures building materials and cement, and is engaged in housing and land development, construction, marine transportation, financial services, and venture capital investment. Flintkote is engaged in mining, and manufactures various building and construction materials, including gypsum wallboard, floor tile, sand and gravel products, concrete, cement and various lime products.

\section{Gulf \& Western Industries / Simmons Co.}

Gulf and Western is a conglomerate with interests in the manufacture of automotive and airconditioning components, paper products, leisure, financial services, automotive replacement parts, consumer products sugar growing and processing, citrus farming, natural resources, and apparel. Simmons produces furnishings for home, commercial and institutional customers.

\section{Harris Corp./Lanier Business Products Inc.}

Harris designs and produces voice and video communication, and information processing systems, equipment, and components. Lanier develops, manufactures, and services a broad line of dictating equipment, several models of video-display text-editing typewriters, and small business computers.

\section{Holiday Inns Inc/ / Harrahs}

Holiday Inns owns and operates hotels throughout the world. Harrahs operates two luxury hotel/casinos.

\section{Internorth Inc,/ Belco Petroleum Corp.}

Intermorth owns and operates natural gas businesses; produces, transports, and markets liquid fuels and petrochemicals; and is involved in the exploration and production of oil and gas. Belco is engaged in the exploration and production of crude oil and natural gas, and the production of coal.

\section{Kroger Inc./ Dillon Companies Inc.}

Kroger operates the country's second largest supermarket chain; manufactures and processes food for sale by these supermarkets; and operates one of the country's largest drugstore chains. Dillon distributes retail food through supermarkets and convenience stores.

\section{Litton Industries / Itek Corp.}

Litton produces advanced electronics products for defense, industrial automation and geophysical 
markets. Itek develops and manufactures a variety of aerial reconnaissance and surveillance products based on optical and electronic technologies.

\section{LTV Group / Republic Steel}

LTV and Republic are respectively the nation's third and seventh largest steel producers.

\section{Mapce Inc./ Earth Resources Company}

Mapco is a diversified energy company principally engaged in the exploration and production of coal, oil, natural gas, and natural gas liquids; pipeline transportation of natural gas liquids and anhydrous ammonia; and marketing natural gas liquids, refined petroleum products, domestic and foreign crude oil, and liquid fertilizers. Earth Resources is a diversified energy and resources development company engaged primarily in refining, transporting and marketing petroleum products.

\section{McGraw-Edison Co./ Studebaker Worthington Inc.}

McGraw-Edison manufactures and distributes products electrical appliances, tools and other products for the consumer market; power system and related equipment for electrical utilities and industry; and a wide range of services and equipment for industrial and commercial uses. Studebaker Worthington's business operations are the manufacture of process equipment and industrial products.

32. Motorola Inc./Four-Phase Systems Inc.

Motorola produces data communication equipment and systems, semiconductors, and other high technology electronic equipment. Four-Phase produces clustered video display computer systems for distributed data processing applications.

\section{Morton-Norwich Products / Thiokol Corporation}

Morton-Norwich produces salt for domestic and industrial uses, household cleaning and laundry products, and specialty chemicals. Thiokol manufactures specialty chemical products, and propulsion and ordnance products and services for the government.

\section{Occidental Petroleum / Cities Service Company}

Occidental produces and markets crude oil and coal, and manufactures industrial chemicals and plastics, metal finishes, agricultural chemicals, and fertilizers. Cities Service is an integrated oil company.

\section{Pan Am Corp./ National Airlines Inc.}

Pan Am is a commercial air carrier providing services to ten cities in the United States, its territories and possessions, and 58 cities in 43 foreign countries. National Airlines provides scheduled air transportation of persons, property and mail over routes extending from its hub in Miami, to New York, San Francisco and Los Angeles, and transatlantic service to London, Paris, Frankfurt and Amsterdam.

\section{Penn Central Corp/GK Technologies Inc.}

Penn Central is a diversified company whose primary businesses include oil refining, transporting and marketing refined petroleum products and crude, real estate development, operating amusement parks, and producing offshore drilling rigs. GK Technologies produces wire and cable primarily for the telecommunications industry, electronic components, and provides engineering services for weapons systems and environmental products. 


\section{Phillips Petroleum / General American Oil of Texas}

Phillips Petroleum is a fully integrated oil company engaged in petroleum exploration, production, and refining. General American is primarily engaged in oil and gas production and exploration.

\section{Raytheon Corp/Beech Aircraft Core.}

Raytheon develops and manufactures electronic systems for government and commercial use. Raytheon is also supplies energy services, manufactures major home appliances, designs and manufactures heavy construction equipment, and publishes textbooks. Beech Aircraft designs, manufactures, and sells airplanes for the general aviation market. Beech is also a substantial aerospace contractor producing a variety of military aircraft, missile targets, and cryogenics systems for aerospace vehicles.

\section{Revlon Inc./ Technicon Corp.}

Revlon is in the beauty products and health products and service business. Technicon designs and produces automated testing systems for blood and other biological fluids, chemical reagents and consumables, industrial analytical instruments, and medical information systems.

\section{R.J. Reynolds Corp./ Del Monte Corp.}

R.J. Reynolds' lines of business are the domestic and international manufacture and sale of tobacco products, transportation (container size freight transportation systems carrying general cargo), energy (oil and gas products), food and beverage products, and aluminum products and packaging. Del Monte's principal business is in food products (primarily processed foods, and fresh fruit), and related services (including transportation, and institutional services).

\section{Signal Companies / Wheelabrator Frye Inc.}

Signal is a diversified, technology-based company which manufactures aerospace equipment, professional audio-video systems, and heavy trucks. Wheelabrator Frye's products and services include environmental, energy and engineered products and services, and chemical and specialty products.

\section{Smithkline Corp./ Beckman Instruments Inc.}

Smithkline researches, develops, manufactures, and markets ethical drugs, proprietary medicines, animal health products, ethical and proprietary eye care products, and ultrasonic and electronic instruments. Beckman is an international manufacturer of laboratory analytical instruments and related chemical products that are used widely in medicine and science, and in a broad range of industrial applications.

\section{Sohie / Kennecott Corp.}

Sohio is an integrated petroleum company engaged in all phases of the petroleum business. Kennecott produces copper, gold, silver, molybdenum and lead; manufactures industrial abrasive and resistant materials; manufactures and markets industrial engineered systems; and owns twothirds of a Canadian producer of titanium dioxide slag, high purity iron, and iron powders.

\section{Standard Brands Nabisco Inc.}

Nabisco is a manufacturer and marketer of food products (specializing in cookies and crackers), toiletries, pharmaceuticals, and household accessories. Standard Brands is a manufacturer, processor and distributor of food and related products. 
45. Tenneco / Houston Oil \& Minerals Corp.

The major businesses of Tenneco are integrated oil and gas operations, natural gas pipelines, construction and farm equipment, automotive components, shipbuilding, chemicals, packaging, agriculture and land management, and life insurance. The recent business emphasis of Houston Oil \& Minerals has been on the exploration for oil and natural gas on undeveloped properties, and the development of production upon discovery.

46. Tosce Corp/ AZL Resources Inc.

Tosco owns and operates petroleum refineries and related wholesale distribution facilities. AZL has been in the process of changing its focus from agricultural-based businesses to oil and gas exploration and production.

47. U.S. Steel / Marathon Oil Co.

U.S. Steel's principal business include steel, chemicals, resource development, fabricating and engineering, and transportation. Marathon is an integrated petroleum company engaged in the production, refining, and transportation of crude oil, natural gas and petroleum products

\section{United Technologies / Carrier Corp}

United Technologies designs and produces high-technology power systems, flight systems, and industrial products and services. Carrier's principal business is the manufacture and sale of air conditioning equipment.

49. Westinghouse Electric / Teleprompter Corp.

Westinghouse Electric is a diversified corporation primarily engaged in the manufacture and sale of electrical equipment. Westinghouse's wholly owned subsidiary WBC operates six TV stations, 12 radio stations, and cable television systems. Teleprompter is nation's largest cable television company, and owns MUZAC, the leading supplier of music to offices and other commercial establishments.

\section{Williams Companies / Northwest Energy Company}

Williams is primarily engaged in the chemical fertilizer, energy and metals businesses. Northwest is primarily engaged in interstate natural gas transmission, oil and gas exploration, and marketing natural gas liquids. 



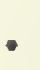





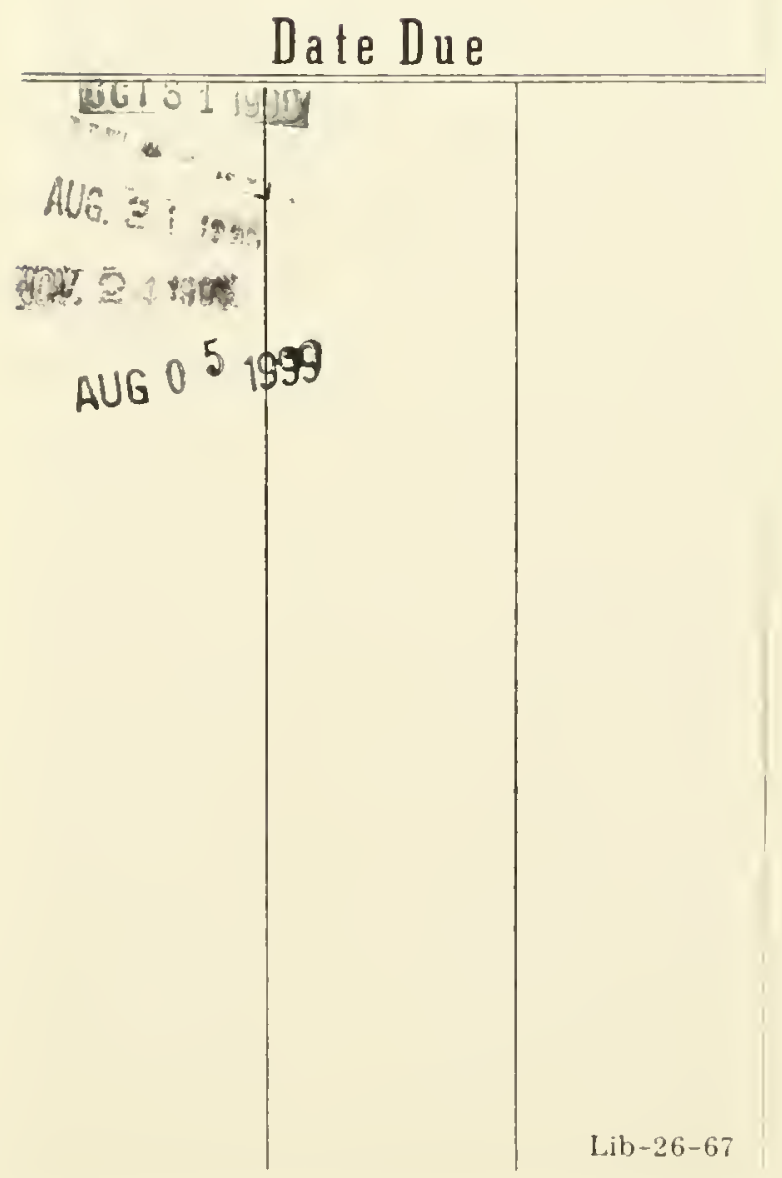




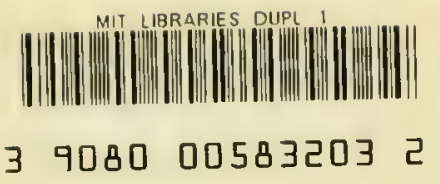


